\title{
The Attitude of Agricultural Extension Personnel towards Utilization of Internet in Farm Communication: A Case Study
}

\author{
Anil Kumar Malik ${ }^{1 *}$ and Krishan Yadav ${ }^{2}$ \\ ${ }^{1}$ Department of Extension Education, College of Agriculture, Chaudhary Charan Singh \\ Haryana Agricultural University, Hisar, Haryana - 125004, India \\ ${ }^{2}$ Directorate of Extension Education, Chaudhary Charan Singh Haryana Agricultural \\ University, Hisar, Haryana - 125004, India \\ *Corresponding author
}

A B S T R A C T

\section{Keywords \\ Attitude, Internet, Extension Personnel, Farmer, Agriculture \\ Article Info \\ Accepted: \\ 16 August 2018 \\ Available Online: \\ 10 September 2018}

Now a day the significance of internet in agriculture are very great and it plays imperative role and speeded the potential of extension personnel to reach the farmers. The present study was conducted at Chaudhary Charan Singh Haryana Agricultural University, Hisar, Haryana. A total of 108 extension personnel (23 at main campus and 85 at outstations) were included in the sample of study. A pre-tested structured questionnaire was used to educe information from the respondents. The data were analyzed using appropriate statistics tool. The findings showed that majority of the respondents had positive attitude towards internet using as a extension tool and also illustrated that it plays an vital role in efficient functioning during their office hours.

\section{Introduction}

Extension methods are plans implemented to set up situations in which latest information and knowledge can pass freely between extension workers and their intended audiences (Obibuaku, 1983). Mass extension methods such as television, radio, circular letters, newspapers, banners, magazines, and brochures were successfully used in numerous countries to carry out extension educational programs (Qamar, 2016). Modern communication tools play an important role in recuperating the availability of market information and farmer assistance in developing countries (Infodev, 2009). There is an awful need to utilize information technology to access the most recent information at a reduced cost relative to the existing system, which is ample with human imperfections and affectations (Adekoya, 2007).

E-extension is the conveyance of extension service using web tools, which allow online sharing, collaboration, and networking (Renwick 2009). Examples of these web tools comprise websites, networking software, online sharing tools such as emails, blogs, and surveys, video conferencing, instant messaging, community-based telecenters, and mobile phones. E-extension as a modern mode 
of communication can be used to enhance the effectiveness and efficiency of extension services. It is a collaboratively built Internetbased environment to improve face-to-face and paper-based transactions, which can also be used as an electronic tool delivering sound and the recent information on agriculture.

It has been reported in many studies and literature that the attitude of an individual plays a significant role in the adoption or rejection of an innovation. The success or failure of any programme or activity to a large extent depends upon the favourable attitude of its clientele towards the proposed programme.

In earlier decade's internet have proved their potentialities in term of accuracy, cost effectiveness, speed, quality, quantity and timeliness. Keeping in mind the enormous scope of internet application in agriculture the entire study was undertaken.

\section{Materials and Methods}

\section{Locale of study}

The present study was conducted at CCS Haryana Agricultural University, Hisar, Haryana. In terms of extension, university covers the entire state through its 19 Krishi Vigyan Kendras (KVKs) located at district headquarters, Directorate of Extension Education (DEE), Agricultural Technology Information Centre (ATIC) and Associate Director Training (ADT) at main campus. Its main aim is to transfer the well proven/tested technology to the farmers (males and females), livestock owners, rural youth, field staff of State Govt. and other personnel engaged in developmental and professional agencies in the sphere of agriculture, animal husbandry, horticulture, home agencies and other allied areas through its well planned, skill-oriented and need-based programmes.

\section{Sample}

University extension personnel serving at main campus along with extension personnel from outstations were taken as the sample. The list of extension personnel from the official website of CCSHAU, which has been considered as the 'universe of the study'.

The total 23 extension personnel were available from main campus and 85 from outstation. The total sample size was 108 respondents. The main tool used for collecting data from the respondents in the present study was a questionnaire.

After pre-testing, necessary modifications have been incorporated in the light of response received. The researchers themselves visited all the KVKs and DEE/ADT/ATIC and collected the information personally.

Descriptive group statistics (frequency, percentage, mean, rank order and standard deviation) of all the respondents were computed through SPSS-21 software. Later on, using the code sheet and SPSS, tables were prepared on MS Excel.

\section{Results and Discussion}

\section{Background of extension advisory personnel}

Many of the extension personnel $(78.70 \%)$ work at the district level. Male personnel $(82.41 \%)$ outnumbered their female counterparts $(17.59 \%)$ at both main campus and outstations. Majority of extension personnel $(45.38 \%)$ have worked for more than 15years. Although there were not a single young personnel (upto 35 years) and most of personnel were middle-aged (36 -50 years). Majority of the respondents $(96.29 \%)$ were Doctorate (Ph.D.) and only 3.71percent respondents were Post Graduate (M. Sc). 


\section{Role of internet as an extension tool}

Table 1 depicts that 77.78 percent of the total respondents evaluated the internet as a 'positive tool' of extension.

Whereas 12.03 percent respondents evaluated the internet as 'negative tool' of extension and remaining 10.19 percent were 'not in a position' to evaluate it.

The above mentioned results indicated that majority of the respondents were of the view that internet could be used as effective tool of farm advisory services.

The similar study conducted by Annamalai and Rao (2003) found that people benefited by weather information, best agricultural practices, customized crop feedback and quality solutions, intelligent fertilizer and pesticide deployment. Middlemen were eliminated and farmers got better price of their produce.

\section{Contribution of internet in official work performance}

When respondents asked about percent contribution of internet in official work performance, $30.55 \%$ of the respondents were of the view that internet contributed 51-75 percent in their official work. Whereas contribution of $0-25 \%, 26-50 \%$ and $76-100 \%$ in official work performance was almost equally divided with 25 percent, 23.14 percent, and 21.29 percent respectively. When compared between main campus and outstation respondents, $26-50 \%$ contribution group topped the main campus with 43.47 percent and $51-75 \%$ group contribution topped outstation with 35.55 percent respondents.

Table.1 Role of internet as an extension tool

\begin{tabular}{|c|lc|c|c|c|c|c|c|}
\hline $\begin{array}{c}\text { S. } \\
\text { No. }\end{array}$ & Role of internet & N & $\%$ & $\begin{array}{l}\text { Total } \\
\text { Score }\end{array}$ & $\begin{array}{c}\text { Rank } \\
\text { order }\end{array}$ & Mean & St. dev. \\
\hline 1. & Positive & $(1)$ & 84 & 77.78 & 84 & I & & \multirow{2}{*}{ (1) } \\
\hline 2. & Negative & $(2)$ & 13 & 12.03 & 26 & III & 1.32 & 0.65 \\
\hline 3. & Can't say & $(3)$ & 11 & 10.19 & 33 & II & & \\
\hline
\end{tabular}

Table.2 Contribution of internet in official work performance

\begin{tabular}{|c|c|c|c|c|c|c|c|}
\hline \multirow[t]{3}{*}{ S. No. } & \multirow{3}{*}{$\begin{array}{l}\text { Per cent contribution of } \\
\text { internet in official work } \\
\text { performance }\end{array}$} & \multicolumn{4}{|c|}{ Extension personnel } & \multirow{2}{*}{\multicolumn{2}{|c|}{$\begin{array}{c}\text { Combined } \\
(\mathrm{N}=108)\end{array}$}} \\
\hline & & \multicolumn{2}{|c|}{$\begin{array}{l}\text { Main Campus } \\
(\mathbf{N}=23)\end{array}$} & \multicolumn{2}{|c|}{$\begin{array}{c}\text { Out Station } \\
(\mathbf{N}=\mathbf{8 5})\end{array}$} & & \\
\hline & & $\mathbf{N}$ & $\%$ & $\mathbf{N}$ & $\%$ & $\mathbf{N}$ & $\%$ \\
\hline 1. & $00-25$ & 8 & 34.78 & 19 & 22.35 & 27 & 25.00 \\
\hline 2. & $26-50$ & 10 & 43.47 & 15 & 17.64 & 25 & 23.14 \\
\hline 3. & $51-75$ & 3 & 13.04 & 30 & 35.50 & 33 & 30.55 \\
\hline 4. & $76-100$ & 2 & 8.69 & 21 & 24.70 & 23 & 21.29 \\
\hline
\end{tabular}


Table.3 Impact of internet on personal adjustments and well-being

\begin{tabular}{|r|l|l|l|l|c|c|c|c|}
\hline $\begin{array}{r}\text { S. } \\
\text { No. }\end{array}$ & \multicolumn{2}{|c|}{$\begin{array}{c}\text { Impact of internet on } \\
\text { personal adjustments }\end{array}$} & N & $\%$ & $\begin{array}{c}\text { Total } \\
\text { Score }\end{array}$ & $\begin{array}{c}\text { Rank } \\
\text { Order }\end{array}$ & Mean & St. dev. \\
\hline 1. & Strongly agree & $(5)$ & 34 & 31.48 & 170 & I & 3.45 & 1.38 \\
\hline 2. & Agree & $(4)$ & 25 & 23.14 & 100 & II & \\
\hline 3. & Neutral & $(3)$ & 16 & 14.81 & 48 & III \\
\hline 4. & Disagree & $(2)$ & 22 & 20.37 & 44 & IV & \\
\hline 5. & Strongly disagree & $(1)$ & 11 & 10.18 & 11 & V & \\
\hline
\end{tabular}

Table.4 Impact of the internet on moral and cultural values

\begin{tabular}{|r|l|l|l|c|c|c|c|}
\hline $\begin{array}{r}\text { S. } \\
\text { No. }\end{array}$ & $\begin{array}{l}\text { Impact of the internet on } \\
\text { moral and cultural values }\end{array}$ & N & $\%$ & $\begin{array}{c}\text { Total } \\
\text { Score }\end{array}$ & $\begin{array}{c}\text { Rank } \\
\text { Order }\end{array}$ & Mean & St. dev. \\
\hline 1. & Strongly agree & $(5)$ & 29 & 26.85 & 145 & I & \\
\hline 2. & Agree (4) & 30 & 27.77 & 120 & II & \\
\hline 3. & Neutral $\quad(3)$ & 17 & 15.74 & 51 & III & 3.40 & 1.35 \\
\hline 4. & Disagree (2) & 20 & 18.51 & 40 & IV & \\
\hline 5. & Strongly disagree (1) & 12 & 11.11 & 12 & V & \\
\hline
\end{tabular}

Fig.1 Map of Haryana showing the study area

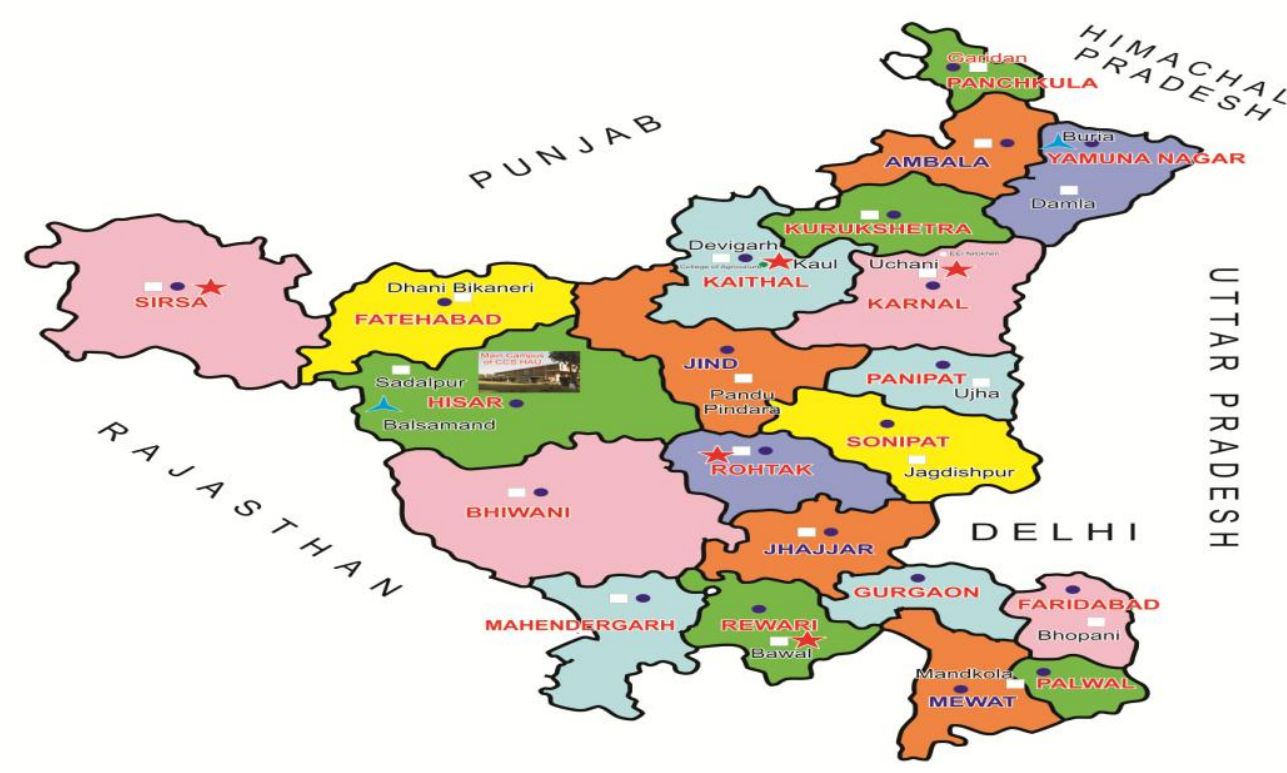

DISTRICT

$\square$ KRISHI VIGYAN KENDRA

* REGIONAL RESEARCH STATION

A SUB STATION 
Fig.2 Role of internet as an extension tool (Table 1)

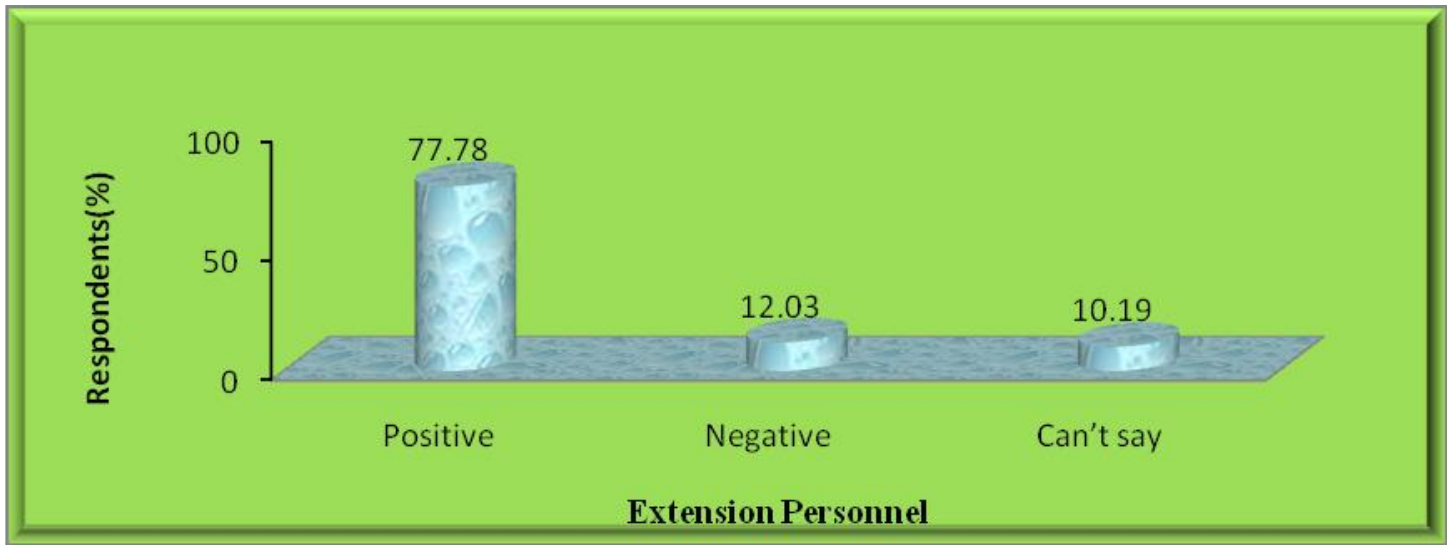

Fig.3 Internet contribution in official work performance (Table 2)

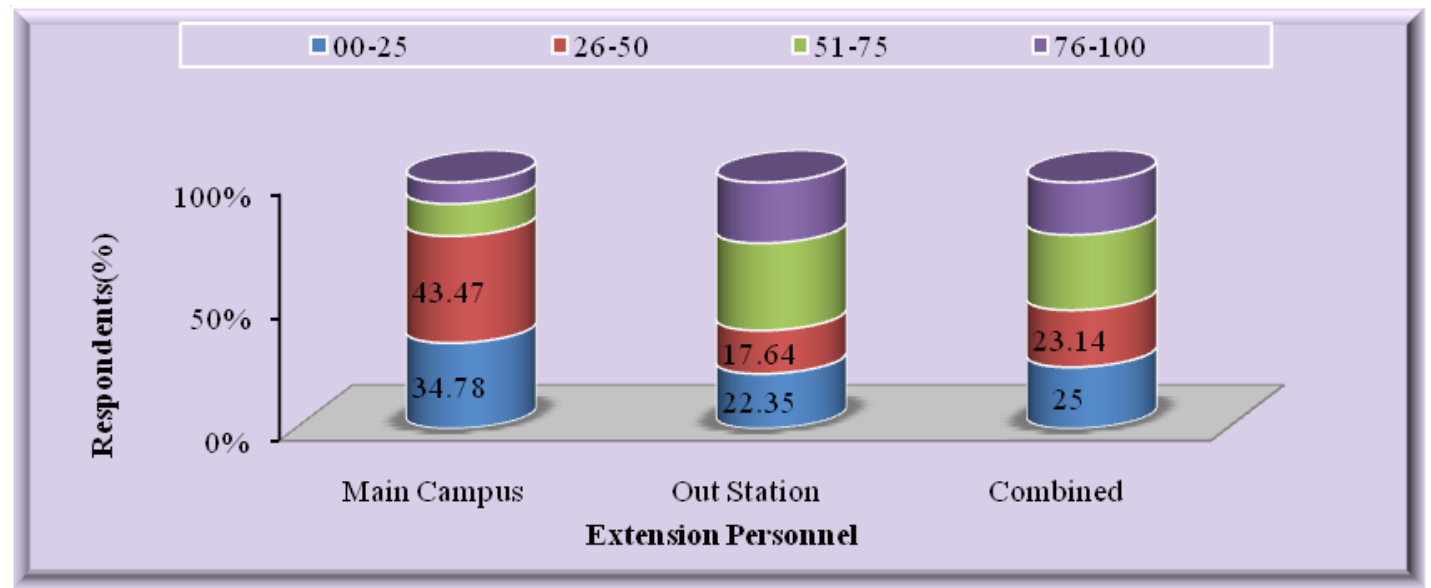

Fig.4 Impact of internet on personal adjustments (Table 3)

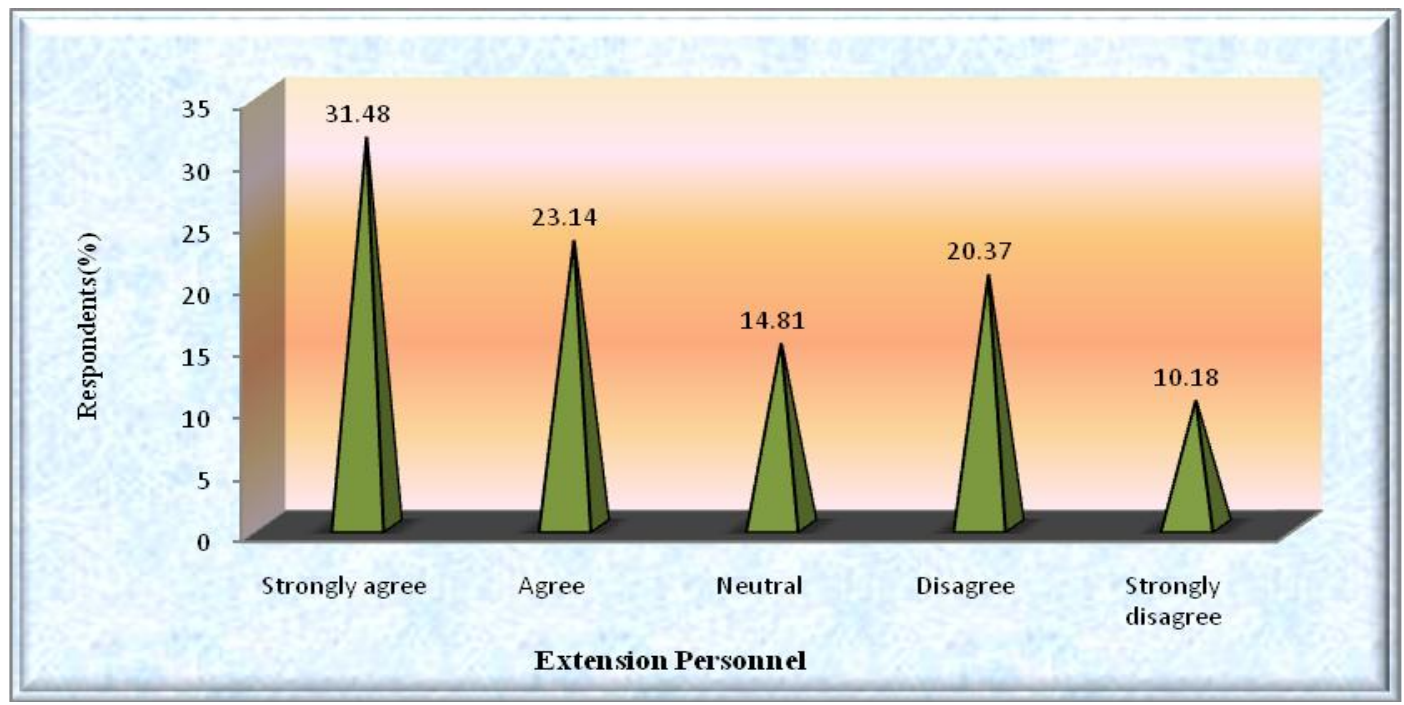


Fig.5 Impact of the internet on moral and cultural values (Table 4)

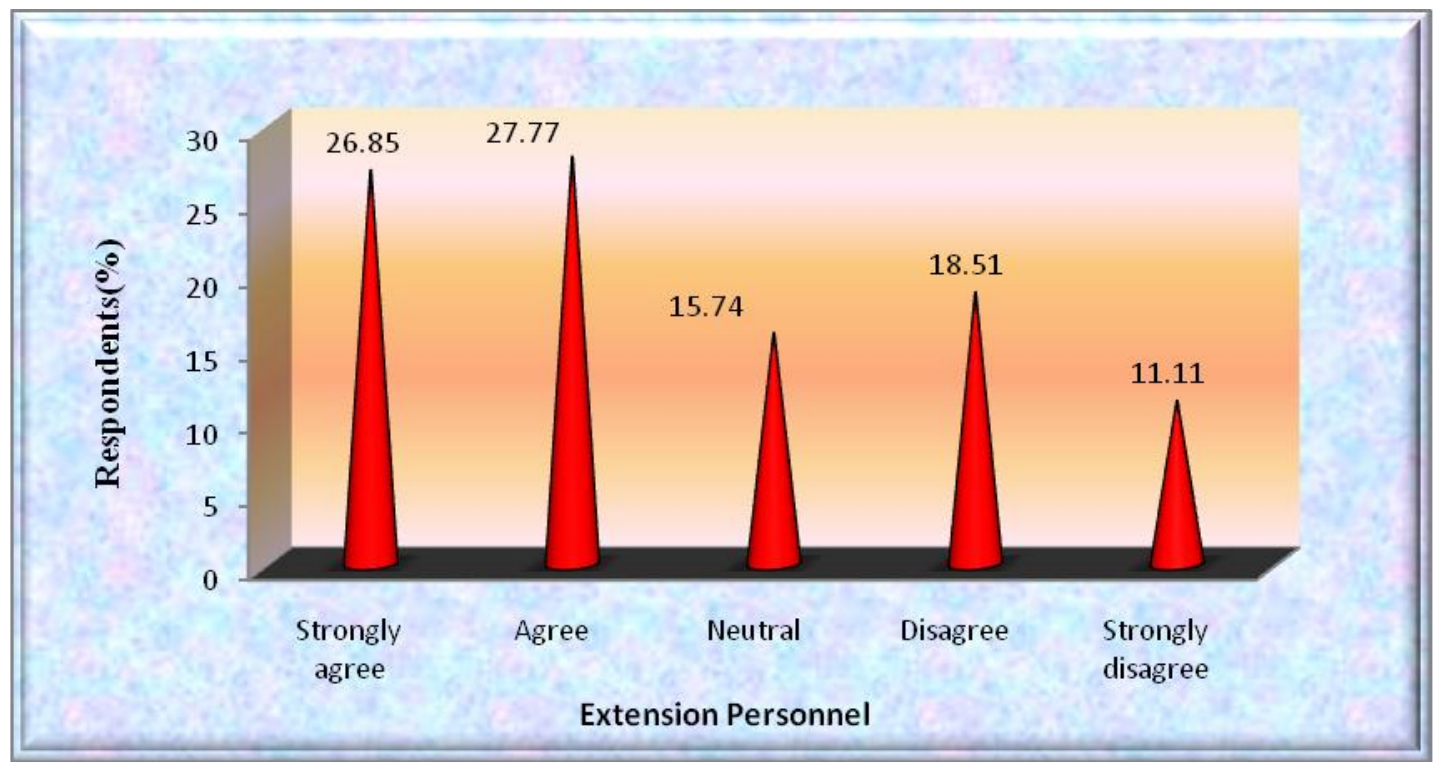

Impact of internet on personal adjustments and well-being

Table 3 illustrates that out of total respondents, 31.48 percent were 'strongly agree' that over 'indulgence with internet affects personal adjustment and well- being', whereas 23.14 percent respondents were 'agree' with it. On the other hand, one- third of the respondents were either 'disagree' $(20.37 \%)$ or 'strongly disagree' $(10.18 \%)$.

\section{Impact of the internet on moral and cultural values}

Table4 depicts that out of total respondents, almost half of the respondents were 'strongly agree' $(26.85 \%)$ or 'agree' $(27.77 \%)$ that 'use of internet put impact on moral and cultural values'. Whereas one-third of the respondents were either 'disagree' (18.51\%) or 'strongly disagree'. The results showed that the extension advisory personnel were divided on this issue.

Results revealed that most of the extension personnel work at outstation (85 out of total 108), had a Ph.D. degree as qualification and are middle-aged (36-50years). Majority of the respondents evaluated the internet as positive tool of extension. But when respondents asked about percent contribution of internet in official work performance, nearly 30 percent of the respondents were of the view that internet contributed $51-75 \%$ in their official work. As far as impact of internet on moral and cultural values is concerned the most, one-fourth of the respondents were strongly agreed with the statement.

\section{References}

Adekoya, A.E. 2007. Cyber extension communication: A strategic model for agricultural and rural transformation in Nigeria. J. Food Agric. Environ, 5. 366-368.

Annamalai, K. and S. Rao. 2003. "What Works: ITC's e-choupal and Profitable Rural Transformation; Web-based Information and Procurement tools for Indian Farmers" available at http://digitaldividend.org/pdf/echoupal_ case.pdf accessed on 5 July 2017.

InfoDev. 2009. ICTs for Sustainable Food Production and Agriculture: 
Technology and Information for the Next Green Revolution. Available online:

http://unpan1.un.org/intradoc/groups/pu blic/documents/unpan/unpan037354.pdf (accessed on 10 July 2017).

Kooganurmath, M. M. and S. Jange. 1999. Use of Internet by social science research scholars: A study in academic libraries in the Internet era. National Convention on Academic Libraries in the Internet Era. Organized by INFLIBNET, Ahmadabad, Pp. 478-83.

Obibuaku, L.O. 1983. Agricultural Extension as a Strategy for Agricultural Transformation; University of Nigeria Press: Nsukka, Nigeria.
Qamar, M.K. 2016. Modernizing National Agricultural Extension Systems: A Practical Guide for Policy Makers of Developing Countries. Available online: ftp://ftp.fao.org/docrep/fao/008/a0219e/ a0219e00.pdf (accessed on 15 July 2017).

Renwick, S. 2009. Potential for Use of Information Communication Technologies (ICT) in Agricultural Extension. Available online: http:// uwispace.sta.uwi.edu/dspace/bitstream/ handle/2139/12632/icts\%20and\%20exte nsion\%20final\%20paper.pdf?sequence= 1 (accessed on 10 July 2016).

\section{How to cite this article:}

Anil Kumar Malik and Krishan Yadav. 2018. The Attitude of Agricultural Extension Personnel towards Utilization of Internet in Farm Communication: A Case Study. Int.J.Curr.Microbiol.App.Sci. 7(09): 2102-2108. doi: https://doi.org/10.20546/ijcmas.2018.709.256 